\title{
Progress towards 14\% Efficient CdTe Solar Cells in Substrate Configuration
}

\author{
Lukas Kranz ${ }^{1}$, Rafael Schmitt ${ }^{1}$, Christina Gretener ${ }^{1}$, Julian Perrenoud ${ }^{1}$, Fabian Pianezzi ${ }^{1}$, Alexander R. Uhl ${ }^{1}$, \\ Debora Keller ${ }^{1}$, Stephan Buecheler ${ }^{1}$, Ayodhya N. Tiwari ${ }^{1}$
${ }^{1}$ Empa - Swiss Federal Laboratories for Materials Science and Technology, Laboratory for Thin Films and Photovoltaics, Ueberlandstrasse 129, Dübendorf, Switzerland

\begin{abstract}
CdTe solar cells are conventionally grown in superstrate configuration. However, the growth in substrate configuration offers more control of junction properties as recrystallization of CdTe and junction formation with $\mathrm{CdS}$ can be decoupled. In this paper the influence of various annealing treatment conditions of the $\mathrm{CdS}$ layer on its morphology and phase and on the device properties is presented. The presence of $\mathrm{CdCl}_{2}$ during this annealing treatment is important for the phase change of the $\mathrm{CdS}$ layer to hexagonal wurtzite and for high efficiencies. $\mathrm{A} \mathrm{CdCl}_{2}$ treatment of the $\mathrm{CdS}$ at $360{ }^{\circ} \mathrm{C}$ improves the efficiency of the device without the adverse effect of pinhole formation in the CdS. CdTe solar cells in substrate configuration with more than $13 \%$ efficiency are achieved as a progress towards $14 \%$ efficiency.
\end{abstract}

Index Terms - II-VI semiconductor materials, Heat treatment, Solar energy, Thin film devices.

\section{INTRODUCTION}

CdTe is one of the most attractive materials for production of low cost thin film solar modules. Conventionally, CdTe solar cells are grown in superstrate configuration. However, the growth in substrate configuration offers the possibility of choosing a variety of substrate materials including metal foils, which enable high-throughput roll-to-roll manufacturing. Furthermore, substrate configuration offers more control of junction properties as CdS is deposited after recrystallization of CdTe. This has several advantages for independent optimization of the electronic properties and the junction formation. In spite of these advantages, the growth in substrate configuration has so far resulted in significantly lower efficiencies than in superstrate configuration, typically well below $10 \%$ and a few examples crossing $10 \%$ efficiency $[1,2]$.

An important processing step for the growth of CdTe solar cells is the junction formation. In superstrate configuration, the junction is formed during the $\mathrm{CdCl}_{2}$ treatment of the $\mathrm{CdS} / \mathrm{CdTe}$ layer stack, which also leads to the recrystallization of the CdTe and CdS layers. While this process is well established, the best junction formation process for substrate configuration is under debate. Various approaches were used for substrate configuration, e.g. a $\mathrm{CdCl}_{2}$ treatment only after CdTe [1-3], a $\mathrm{CdCl}_{2}$ treatment of the CdTe-CdS layer stack [4], or a $\mathrm{CdCl}_{2}$ treatment after both $\mathrm{CdTe}$ and $\mathrm{CdS}[1,3,5]$.

We obtain best performance with separate $\mathrm{CdCl}_{2}$ treatments of the CdTe and CdS. This approach enables independent control over the recrystallization of the CdTe and the junction formation with $\mathrm{CdS}$. We show that the presence of $\mathrm{CdCl}_{2}$ is important during the annealing treatment of the CdS and that the oxygen content of the annealing ambient has to be controlled. Furthermore, we show that the addition of a second CdS layer after the annealing treatment of the first CdS layer improves open circuit voltage $\left(\mathrm{V}_{\mathrm{OC}}\right)$ and fill factor $(\mathrm{FF})$. Performing the $\mathrm{CdCl}_{2}$ treatment at $360{ }^{\circ} \mathrm{C}$ improves the electronic properties without adverse effect on the microstructure of CdS. Substrate configuration CdTe solar cells with efficiency of more than $13 \%$ are produced.

\section{EXPERIMENTAL}

$\mathrm{CdS} / \mathrm{CdTe}$ solar cells in substrate configuration were grown on $\mathrm{Mo} / \mathrm{MoO}_{\mathrm{x}}$ covered Corning 7059 glass. In some cases a Te layer was added on top of the $\mathrm{MoO}_{\mathrm{x}}$. CdTe was deposited by vacuum evaporation at $350{ }^{\circ} \mathrm{C}$ followed by a recrystallization and doping treatment [6]. CdS was deposited by chemical bath deposition (CBD). A $\mathrm{CdCl}_{2}$ treatment of the $\mathrm{CdS}$ was performed by vacuum evaporation of $100 \mathrm{~nm}$ of $\mathrm{CdCl}_{2}$ followed by annealing at different temperatures and oxygen contents of the annealing ambient as stated in the text. In some cases a second $\mathrm{CdS}$ layer was deposited by chemical bath deposition. A double layer of $\mathrm{i}-\mathrm{ZnO} / \mathrm{ZnO}: \mathrm{Al}$ was deposited by sputtering followed by a Ni/Al grid and $\mathrm{MgF}_{2}$ anti-reflection coating by electron beam evaporation.

The performance of the solar cells was measured with current density voltage (J-V) measurements under simulated standard test conditions in a sun simulator and quantum efficiency (QE) measurements were performed for spectral mismatch correction.

Scanning electron microscopy (SEM) images of the first $\mathrm{CdS}$ layer deposited on glass $/ \mathrm{Mo} / \mathrm{MoO}_{\mathrm{x}} / \mathrm{CdTe}$ and annealed under different conditions were acquired with a Hitachi S4800 operated at an accelerating voltage of $5 \mathrm{kV}$.

Samples for scanning transmission electron microscopy (STEM) were prepared by mechanical polishing of crosssections followed by Ar ion milling using a Fischione TEM ion mill 1050 employing the liquid nitrogen cooling option. STEM analysis was performed on a JEOL 2200FS TEM/STEM operated at $200 \mathrm{kV}$. 
TABLE I

PHOTOVOLTAIC (PV) PARAMETERS OF CDTE SOLAR CELLS PROCESSED WITH DIFFERENT CDS ANNEALING CONDITIONS.

\begin{tabular}{|c|c|c|c|c|c|c|c|c|}
\hline \multicolumn{3}{|c|}{$\begin{array}{c}\text { Annealing conditions of } \\
1^{\text {st }} \mathrm{CdS} \text { layer }\end{array}$} & \multirow[t]{2}{*}{$\begin{array}{c}2^{\text {nd }} \mathrm{CdS} \\
\text { layer }\end{array}$} & \multicolumn{4}{|c|}{ PV parameters } & \multirow[t]{2}{*}{$\begin{array}{c}\text { SEM } \\
\text { image }\end{array}$} \\
\hline $\begin{array}{c}\text { Temp. } \\
{ }^{\circ} \mathrm{C}\end{array}$ & $\begin{array}{c}\mathrm{O}_{2} \\
\text { vol \% }\end{array}$ & $\mathrm{CdCl}_{2}$ & & $\begin{array}{l}\mathrm{V}_{\mathrm{OC}} \\
\mathrm{mV}\end{array}$ & $\begin{array}{c}\mathrm{Jsc}_{\mathrm{sc}} \\
\mathrm{mA} / \mathrm{cm}^{2}\end{array}$ & $\begin{array}{l}\mathrm{FF} \\
\%\end{array}$ & $\begin{array}{c}\text { Eff. } \\
\%\end{array}$ & \\
\hline \multicolumn{3}{|c|}{ No annealing } & no & 703 & 20.1 & 54.4 & 7.7 & $a$ \\
\hline 400 & 50 & yes & no & 812 & 21.6 & 67.1 & 11.8 & $b$ \\
\hline 400 & 50 & yes & yes & 830 & 20.2 & 72.5 & 12.2 & - \\
\hline 400 & 30 & yes & yes & 688 & 21.3 & 64.6 & 9.5 & c \\
\hline 400 & 80 & yes & yes & 709 & 21.4 & 65.8 & 9.9 & $\mathrm{~d}$ \\
\hline 400 & 50 & no & yes & 711 & 20.5 & 59.8 & 8.7 & $\mathrm{e}$ \\
\hline
\end{tabular}
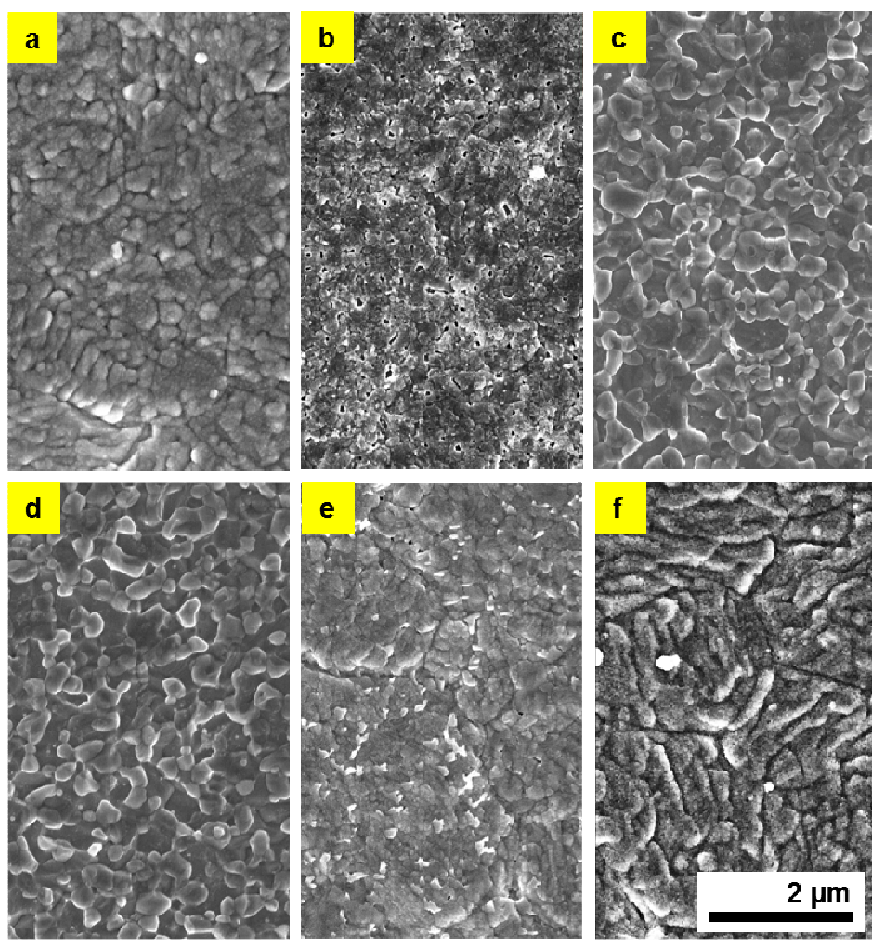

Fig. 1. Top view SEM images of as-deposited CdS on CdTe (a) and CdS deposited on CdTe and annealed under different conditions (b-f). All SEM figures show the morphology of the $1^{\text {st }} \mathrm{CdS}$ layer without addition of a $2^{\text {nd }} \mathrm{CdS}$. Annealing conditions of b-e are shown in Table I. Sample $\mathrm{f}$ is processed at $360{ }^{\circ} \mathrm{C}, 50 \% \mathrm{O}_{2}$, with $\mathrm{CdCl}_{2}$.

In-situ X-ray diffraction (XRD) patterns were recorded using a PANanalytical XPert Pro MPD X-ray diffractometer. A $2 \theta$ scan was recorded with fixed grazing incidence angle of $3^{\circ}$. XRD patterns of a solar cell processed up to the first $\mathrm{CdS}$ layer were recorded at temperatures between $150^{\circ} \mathrm{C}$ and 450 ${ }^{\circ} \mathrm{C}\left(10{ }^{\circ} \mathrm{C}\right.$ steps, $1.5^{\circ} \mathrm{C} / \mathrm{min}$ ramping speed $)$ in an ambient containing $50 \%$ of oxygen. The experiment was performed both with and without a $\mathrm{CdCl}_{2}$ layer on the $\mathrm{CdS}$.

\section{RESULTS AND DISCUSSION}

Fig. 1 shows the top view SEM micrographs of CdS layers, which were deposited on the CdTe layer of solar cells in substrate configuration and annealed under different conditions. Table I shows the photovoltaic parameters of the corresponding finished devices. As-deposited CdS grown by CBD covers the CdTe layer with nanocrystalline sized grains (Fig. 1a). Upon a $\mathrm{CdCl}_{2}$ treatment at $400{ }^{\circ} \mathrm{C}$ and $50 \%$ of $\mathrm{O}_{2}$, the microstructure of the CdS layer significantly changes (Fig. 1b): Grain size increases and pinholes are formed in the CdS layer. In spite of the pinhole formation in the CdS layer, the efficiency of the solar cells increases due to improvements in all photovoltaic parameters, especially $\mathrm{V}_{\mathrm{OC}}$ and $\mathrm{FF}$.

Even though the $\mathrm{CdCl}_{2}$ treatment of the $\mathrm{CdS}$ increases efficiency, the pinholes in the CdS layer which occur upon $\mathrm{CdCl}_{2}$ treatment are detrimental to device performance due to the direct contact between $\mathrm{CdTe}$ and $\mathrm{ZnO}$. In order to cover the pinholes and to enable a covering CdS layer, a second CdS layer is grown after the $\mathrm{CdCl}_{2}$ treatment of the first $\mathrm{CdS}$ layer. Even though this leads to increased parasitic absorption in the $\mathrm{CdS}$ window layer and therefore a reduced short circuit current density $\left(\mathrm{J}_{\mathrm{SC}}\right)$, with the application of the second CdS layer $\mathrm{V}_{\mathrm{OC}}$ and $\mathrm{FF}$ are further increased. $\mathrm{V}_{\mathrm{OC}}$ well above $800 \mathrm{mV}$ and $\mathrm{FF}$ above $70 \%$ are obtained (Table I), leading to an increased efficiency of $12.2 \%$.

We have varied the oxygen content during the $\mathrm{CdCl}_{2}$ treatment of the $\mathrm{CdS}$ and have investigated its influence on the $\mathrm{CdS}$ morphology and the device performance. The oxygen content has a strong influence on the CdS morphology and changing the oxygen content from $50 \%$ to $30 \%$ or $80 \%$ leads to pronounced pinhole formation (Fig. 1c \& d). The efficiency is reduced to below $10 \%$ due to a reduction of $\mathrm{V}_{\mathrm{OC}}$ and $\mathrm{FF}$. This shows, that oxygen content during the annealing treatment at $400{ }^{\circ} \mathrm{C}$ has to be well controlled in order to achieve a good morphology of the $\mathrm{CdS}$ with minimal pinhole density and to obtain high efficiencies. 

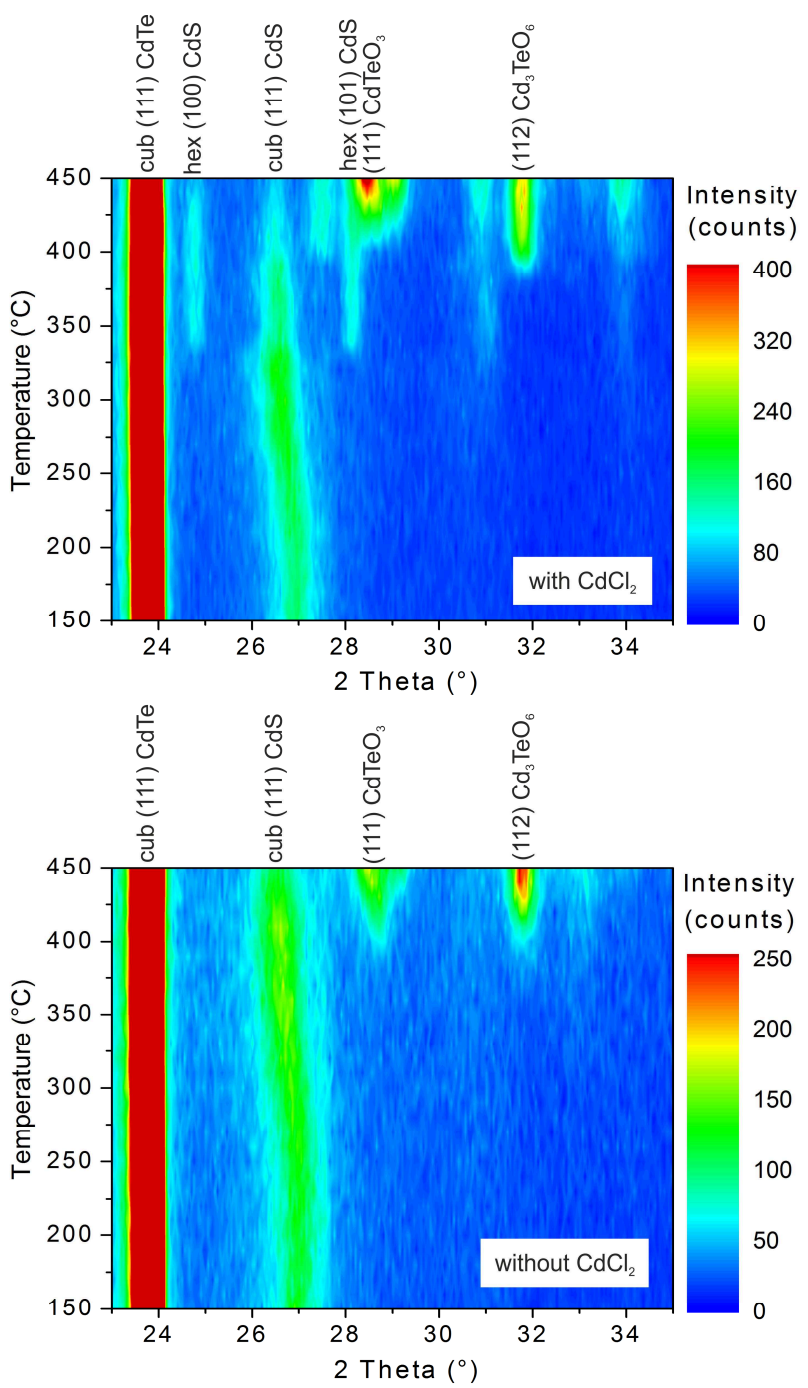

Fig. 2. In-situ XRD patterns during the $\mathrm{CdCl}_{2}$ treatment of $\mathrm{CdS}$ (a) and while annealing without the presence of $\mathrm{CdCl}_{2}$ (b). $\mathrm{CdS}$ was deposited on a Glass/Mo/MoO $/ \mathrm{CdTe}$ layer stack.

Grain growth is a typical influence of the $\mathrm{CdCl}_{2}$ treatment and can lead to pinhole formation. In an attempt to avoid pinhole formation, a sample was identically processed as the device with $12.2 \%$ efficiency but without addition of $\mathrm{CdCl}_{2}$ during the annealing of the CdS. SEM images confirm that this significantly reduces pinhole formation in the CdS (Fig. 1e). In spite of the improved coverage, a low $\mathrm{V}_{\mathrm{OC}}$ of $\sim 700 \mathrm{mV}$ and a low FF of $\sim 60 \%$ are obtained, yielding an efficiency of only $8.7 \%$ (Table I).

It is possible that the annealing conditions of the $\mathrm{CdS}$ (temperature, oxygen content) need to be adapted for an annealing step without $\mathrm{CdCl}_{2}$. Therefore, we have produced several samples with varying annealing conditions of the $\mathrm{CdS}$ without addition of $\mathrm{CdCl}_{2}$. The highest obtained efficiency for a solar cell where the $\mathrm{CdS}$ was annealed without addition of $\mathrm{CdCl}_{2}$ is $11.1 \%\left(799 \mathrm{mV}, 61.2 \% \mathrm{FF}, 22.8 \mathrm{~mA} / \mathrm{cm}^{2}\right)$. This is obtained by reducing oxygen content to $10 \%$ while the temperature is kept at $400{ }^{\circ} \mathrm{C}$. The lower oxygen content reduces oxidation of the $\mathrm{CdS}$, while a reduced oxygen content is not needed when $\mathrm{CdCl}_{2}$ is used, which protects the $\mathrm{CdS}$ layer from oxidation [7]. The efficiencies of cells processed without addition of $\mathrm{CdCl}_{2}$ during the annealing treatment of the CdS always remained significantly lower than what we achieve with addition of $\mathrm{CdCl}_{2}$, especially due to a low $\mathrm{FF}<65 \%$ in samples without addition of $\mathrm{CdCl}_{2}$. Therefore, we conclude, that addition of $\mathrm{CdCl}_{2}$ during the annealing treatment of the $\mathrm{CdS}$ is important for good device performance, especially to obtain high FF.

Even when no $\mathrm{CdCl}_{2}$ is added to the aforementioned samples, a small amount of $\mathrm{CdCl}_{2}$ due to residuals in the annealing oven cannot be excluded. A sample similarly processed as the aforementioned sample with $11.1 \%$ efficiency shows significantly lower efficiencies when the $\mathrm{CdS}$ annealing treatment is performed after removing all residual $\mathrm{CdCl}_{2}$ from the annealing oven. This further emphasizes the importance of the presence of $\mathrm{CdCl}_{2}$ during the annealing treatment of the CdS.

To investigate the influence of the presence of $\mathrm{CdCl}_{2}$ on the crystallographic phase of CdS we have performed in-situ XRD measurements of a solar cell processed up to the $\mathrm{CdS}$ with and without using $\mathrm{CdCl}_{2}$ (Fig. 2). In the presence of $\mathrm{CdCl}_{2}$ the phase of the CdS layer changes from cubic to hexagonal while the phase change does not occur when no $\mathrm{CdCl}_{2}$ is present even when higher than usual annealing temperatures are used. The results suggest that recrystallization of the CdS layer to hexagonal phase is important to obtain high efficiency solar cells. In-situ XRD shows that above $400{ }^{\circ} \mathrm{C}$ various oxides are formed. The shift of the CdS (111) phase towards smaller angles upon annealing is attributed to oxygen loss from the hydro-oxygenated CBD grown $\mathrm{CdS}$. The reduction of oxygen content in the $\mathrm{CdS}$ layer upon $\mathrm{CdCl}_{2}$ treatment is confirmed with secondary ion mass spectroscopy measurements (not shown).

The in-situ XRD results furthermore show, that the phase change of the CdS, which accompanies the improved device performance already occurs at around $330{ }^{\circ} \mathrm{C}$, which is significantly lower than typical $\mathrm{CdCl}_{2}$ treatment temperatures of 400-420 ${ }^{\circ} \mathrm{C}$ commonly applied for CdTe solar cells in superstrate configuration.

We have produced solar cells where the CdS layer was $\mathrm{CdCl}_{2}$ treated at $360{ }^{\circ} \mathrm{C}$. XRD measurements confirm that this temperature also enables the change of phase from cubic to hexagonal CdS. Furthermore as shown in Fig. 1f, the lower temperatures enable an improved coverage of the CdTe layer with hexagonal $\mathrm{CdS}$ compared to the application of $400{ }^{\circ} \mathrm{C}$. Top view SEM images do not reveal a significant change in morphology of the CdS layer upon $\mathrm{CdCl}_{2}$ treatment of the $\mathrm{CdS}$ at $360{ }^{\circ} \mathrm{C}$. However, TEM shows grain growth of the $\mathrm{CdS}$ upon $\mathrm{CdCl}_{2}$ treatment at $360{ }^{\circ} \mathrm{C}$ (Fig. 3). The STEM image shows the double $\mathrm{CdS}$ layer between the $\mathrm{CdTe}$ absorber and the $\mathrm{ZnO}$ front contact. The first, $\mathrm{CdCl}_{2}$ treated $\mathrm{CdS}$ layer exhibits grain size up to several $100 \mathrm{~nm}$ while the additional 
CdS layer exhibits nanocrystallites as commonly observed for CBD grown CdS.

Fig. 4 shows the J-V and QE curve of a cell where the $\mathrm{CdCl}_{2}$ treatment of the $\mathrm{CdS}$ is performed at $360{ }^{\circ} \mathrm{C}$. An efficiency of $13.2 \%$ is obtained with $\mathrm{V}_{\mathrm{OC}}$ and $\mathrm{FF}$ as high as the internal record efficiency cell in superstrate configuration [8], which is shown for comparison. It is also notable, that the rollover, which is generally very pronounced for CdTe solar cells in substrate configuration, is not observed for the cell with $\mathrm{CdS}$ bi-layer.

Even though the modified annealing treatment solves the structural problems of pinhole formation in the $\mathrm{CdS}$, the second CdS layer is still required for highest $\mathrm{V}_{\mathrm{OC}}$ and FF. Fig. 4 shows the J-V and QE curves of a cell without second $\mathrm{CdS}$ which has $13.3 \%$ efficiency. Remarkable $\mathrm{V}_{\mathrm{OC}}$ and $\mathrm{FF}$ are reached, however the values are still lower compared to cells with CdS bi-layer.

The presence of $\mathrm{CdCl}_{2}$ during the annealing treatment of the $\mathrm{CdS}$ is crucial for highest performance and in-situ XRD reveals that the presence of $\mathrm{CdCl}_{2}$ is needed to obtain a phase change of $\mathrm{CdS}$ upon annealing. Furthermore, all high efficiency devices, which were investigated by XRD, had hexagonal CdS. This could hint towards the important role of the hexagonal phase of CdS. However, XRD measurements of a high efficiency superstrate cell revealed cubic CdS. These results indicate that another effect accompanies the phase change of CdS, possibly the diffusion of elements or the modification of the $\mathrm{CdS} / \mathrm{CdTe}$ interface, which lead to improved electronic properties. This will be discussed in future publications.

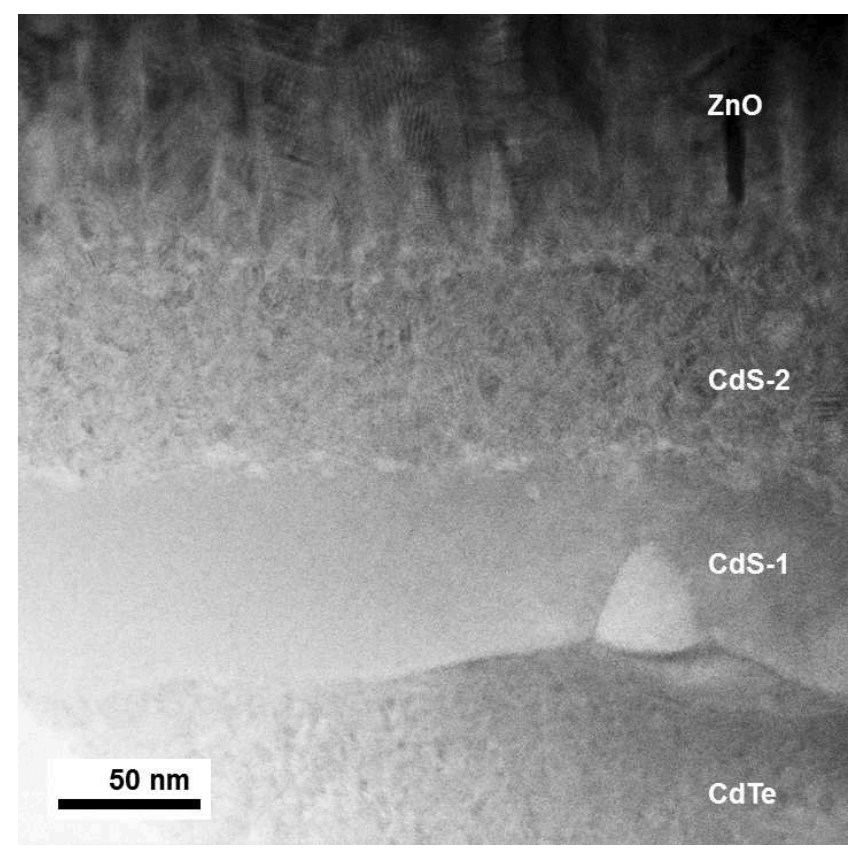

Fig. 3. Bright field STEM image of the double layer CdS in a CdTe solar cell. The first CdS layer (CdS-1) is $\mathrm{CdCl}_{2}$ treated at 360 ${ }^{\circ} \mathrm{C}$ and the second $\mathrm{CdS}$ (CdS-2) is as-deposited CBD grown CdS.
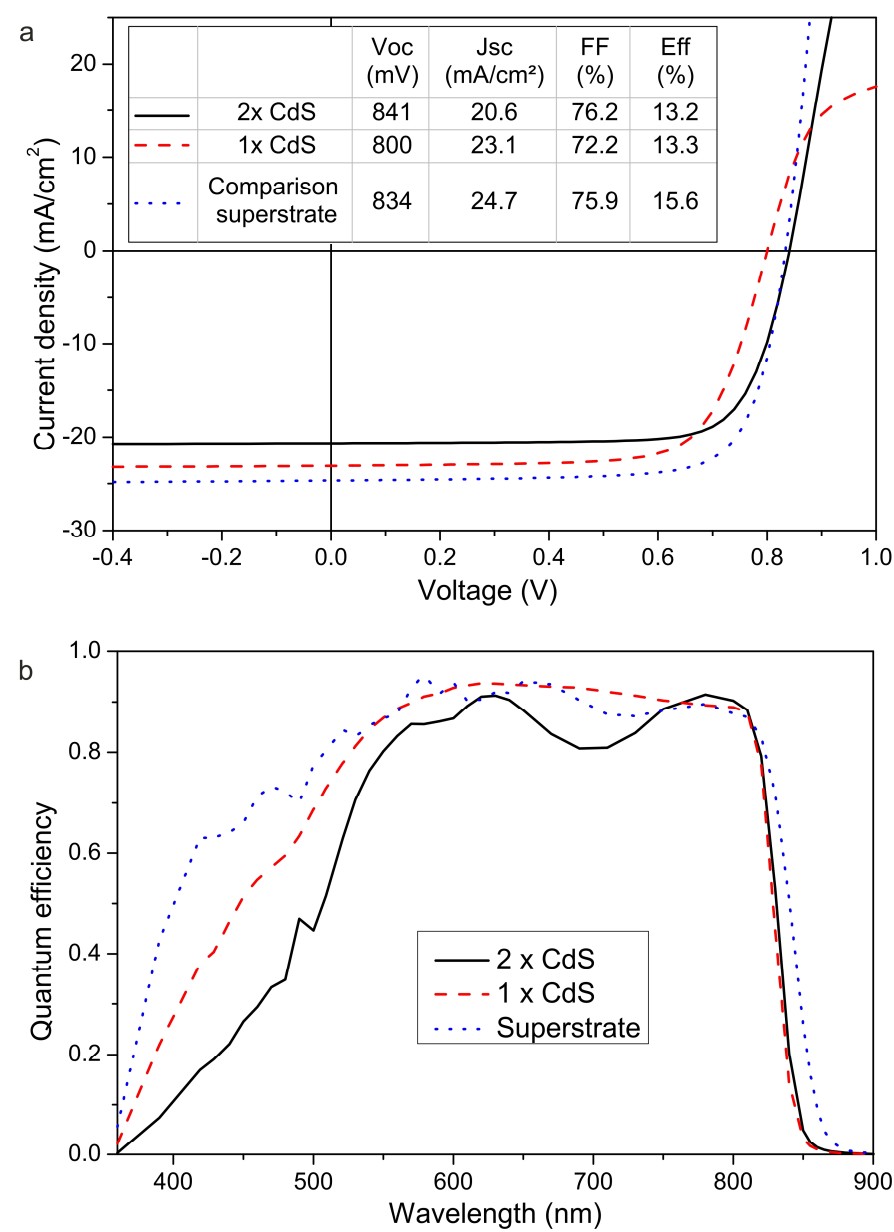

Fig. 4. J-V (a) and QE (b) measurements of cells processed with a $\mathrm{CdCl}_{2}$ treatment of the $\mathrm{CdS}$ at $360{ }^{\circ} \mathrm{C}$ with single and double $\mathrm{CdS}$ layer. Our internal record cell in superstrate configuration is included for comparison [8]. The inset shows the PV parameters of the corresponding cells

The results of high $\mathrm{V}_{\mathrm{OC}}$ and $\mathrm{FF}$ of the cell with CdS bi-layer and the high $\mathrm{J}_{\mathrm{SC}}$ of the cell with single CdS (Fig. 4) suggest that efficiencies well above $14 \%$ should be achievable. However, the increase in $\mathrm{J}_{\mathrm{SC}}$ upon $\mathrm{CdS}$ thickness reduction was accompanied by a decrease in $\mathrm{V}_{\mathrm{OC}}$ and FF so far. In future we will test different approaches to achieve a reduction of $\mathrm{CdS}$ thickness without loss in $\mathrm{V}_{\mathrm{OC}}$ and FF.

\section{SUMMARY \& OUTLOOK}

In conclusion, the influence of different processing conditions during an annealing treatment after deposition of the CdS layer on its morphology and phase as well as on the device properties is investigated. The presence of $\mathrm{CdCl}_{2}$ during the annealing treatment of the $\mathrm{CdS}$ is important for a phase change of the $\mathrm{CdS}$ to hexagonal phase and for high efficiency solar cells. Oxygen content during this annealing treatment has to be well controlled to achieve good $\mathrm{CdS}$ morphology and for improved device performance. 
Performing the $\mathrm{CdCl}_{2}$ treatment at $360{ }^{\circ} \mathrm{C}$ leads to a phase change of the $\mathrm{CdS}$ without adverse effects on the coverage of $\mathrm{CdS}$. CdTe solar cells in substrate configuration with more than $13 \%$ efficiency are achieved. In future publications the effect of the annealing treatment on electronic properties and diffusion of impurities will be further elaborated. Furthermore, we will test different approaches to reduce CdS layer thickness or to substitute CdS by alternative materials in order to further increase efficiency towards and beyond 14\%.

\section{REFERENCES}

[1] C. Gretener, J. Perrenoud, L. Kranz, L. Kneer, R. Schmitt, S. Buecheler, and A. N. Tiwari, "CdTe/CdS thin film solar cells grown in substrate configuration," Prog. Photovolt., DOI: 10.1002/pip.2233, 2012.

[2] J. N. Duenow, R. G. Dhere, D. Kuciauskas, J. V. Li, J. W. Pankow, P. C. Dippo, C. M. DeHart, and T. A. Gessert, "Oxygen incorporation during fabrication of substrate CdTe photovoltaic devices," 38th IEEE Photovoltaic Specialists Conference, pp. 3225-3229, 2012.

[3] R. G. Dhere, J. N. Duenow, C. M. DeHart, J. V. Li, D. Kuciauskas, M. R. Young, K. Alberi, A. Mascarenhas and T. A. Gessert, "Analysis of the junction properties of $\mathrm{CdS} / \mathrm{CdTe}$ devices in substrate and superstrate configurations," Proc. 26th Europ. Photovolt. Solar Energy Conf., pp. 2456-2459, 2011.

[4] I. Matulionis, S. Han, J. A. Drayton, K. J. Price and A. D Compaan, "Cadmium Telluride Solar Cells on Molybdenum Substrates," Proc. Mater. Res. Soc. Symp. 668, H8.23, 2001.

[5] V. P. Singh, J. C. McClure, G. B. Lush, W. Wang, X. Wang, G. W. Thompson and E. Clark, "Thin film CdTe-CdS heterojunction solar cells on lightweight metal substrates," Solar Energy Materials \& Solar Cells 59, pp. 145-161, 1999.

[6] L. Kranz et al., submitted

[7] L. Wan, Z. Bai, Z. Hou, D. Wang, H. Sun, and L. Xiong, "Effect of $\mathrm{CdCl}_{2}$ annealing treatment on thin CdS films prepared by chemical bath deposition," Thin Solid Films, 518, 23, pp. 6858-6865, 2010.

[8] J. Perrenoud, L. Kranz, S. Buecheler, F. Pianezzi and A. N. Tiwari, "The use of aluminum doped $\mathrm{ZnO}$ as transparent conductive oxide for CdS/CdTe solar cells, “ Thin Solid Films 519, pp. 7444-7448, 2011. 